\title{
Koronarangiografi etter hjertestans
}

\author{
Tidlig angiografi etter hjertestans \\ uten ST-elevasjon bedrer ikke \\ overlevelsen, viser multisenter- \\ studie.
}

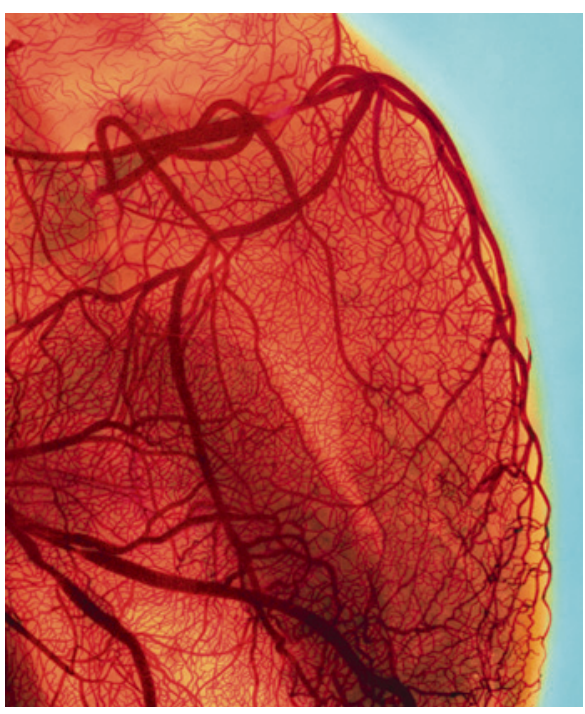

Illustrasjonsfoto: Science Photo Library
Tidlig koronar intervensjon gir økt overlevelse for pasienter med ST-elevasjonsinfarkt.

Akutt ST-hevning tyder på koronar okklusjon, men okklusjon er også til stede hos et signifikant antall overlevende etter hjertestans uten ST-hevning.

I flere retningslinjer anbefales det at angiografi vurderes etter hjertestans, selv der det ikke foreligger ST-elevasjon. Retrospektive studier har imidlertid ikke kunnet bekrefte om dette er fordelaktig eller ikke.

I tidsskriftet Intensive Care Medicine er det nylig publisert en post hoc- analyse av Targeted Temperature Management (TTM)studien (1). Analysen omfattet 544 pasienter med hjertestans og EKG uten ST-elevasjon. Av disse ble 252 pasienter behandlet med koronar intervensjon innen seks timer. Tidlig angiografisk undersøkelse var ikke forbundet med signifikant $ø$ kt overlevelse eller bedret nevrologisk funksjon.

- TTM-studien randomiserte 939 hjertestanspasienter ved 36 sykehus til nedkjøling eller ikke, med median oppfølging på 427 dager, sier overlege og kardiolog Cecilie Risøe ved Oslo universitetssykehus, Rikshospitalet.

\section{Brystkreftscreening ved mammografisk tette bryst}

\author{
Kombinasjonen brystkreftrisiko og mammografisk brysttetthet kan \\ predikere risiko for invasiv brystkreft innen et år etter mammografi.
}

Høy mammografisk tetthet kan maskere svulster og redusere sensitiviteten ved mammografiscreening. Bruk av andre bildeundesøkelser i tillegg til mammografi er vist å øke deteksjonsraten. Hvordan brystkreftrisiko og mammografisk tetthet er assosiert med diagnose av infiltrerende brystkreft innen 12 måneder etter mammografi (intervallkreft), er nå undersøkt i en prospektiv kohortstudie i USA (1).

Rundt halvparten av kvinnene hadde mammografisk tette bryst. For disse var risikoen for intervallkreft lav etter negativt screeningresultat og lav fem års brystkreftrisiko. Kvinner med ekstremt tette bryst og middels eller høy fem års brystkreftrisiko, og de med heterogen brysttetthet og høy eller svært høy fem års risiko, hadde høy risiko for å utvikle intervallkreft ( $>1$ tilfelle/ 1000 mammografiundersøkelser).

- Studier fra det norske mammografiprogrammet viser at kvinner med mammogra- fisk tette bryst har en høyere risiko for å få diagnostisert intervallkreft enn kvinner med fettrike bryst, og at intervallkreft ofte er mer aggressiv og hurtigvoksende enn screeningoppdaget brystkreft, sier leder for Mammografiprogrammet, professor Solveig Hofvind ved Kreftregisteret.

- Funnene fra den amerikanske studien er interessante, men det er nødvendig med studier som kan relateres til norske forhold, og som kan vise at gevinstene er større enn ulempene for kvinnene og samfunnet, før nye prosedyrer kan vurderes, avslutter Hofvind.

\section{Trine B. Haugen}

Tidsskriftet

\section{Litteratur}

1. Kerlikowske K, Zhu W, Tosteson ANA et al. Identifying women with dense breasts at high risk for interval cancer: a cohort study. Ann Intern Med 2015; 162: 673-81.
- Studien er godt gjennomført og inkluderte en bredere populasjon enn andre tilsvarende studier. Svakheten i denne analysen er at pasientene ikke var randomisert til tidlig koronarangiografi eller ikke, og det kan gi en økt seleksjonsbias. I likhet med norske sykehus hadde sentrene i studien ulik praksis hva gjelder tidlig angiografi hos pasienter uten ST-elevasjon. Overlevelse vil avhenge ikke bare av hjertefunksjon, men også av cerebral skade. Analysen er interessant, men erstatter ikke en randomisert studie, sier Risøe.

\section{Liv-Ellen Vangsnes}

Tidsskriftet

Litteratur

1. Dankiewicz J, Nielsen N, Annborn M et al. Survival in patients without acute ST elevation after cardiac arrest and association with early coronary angiography: a post hoc analysis from the TTM trial. Intensive Care Med 2015; 41: 856-64.
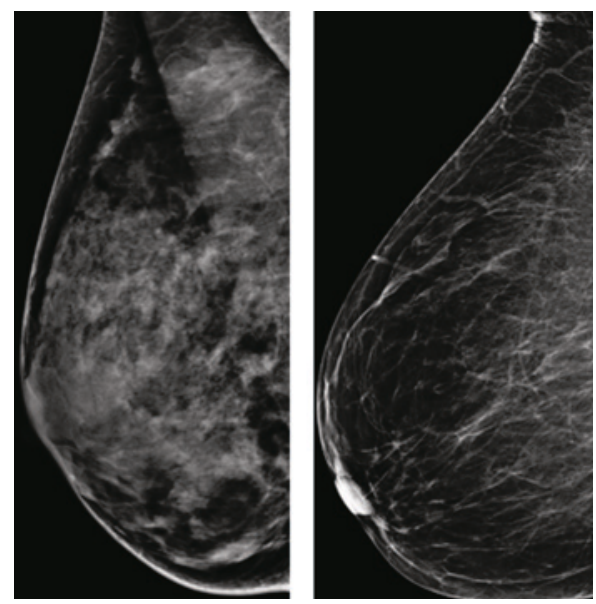

Illustrasjonsfoto: Ap/Scanpix 